\title{
Technology of Formation of Students Communicative Culture in the Process of Learning Foreign Languages
}

\author{
Gulnar Aytzhanova \\ Candidate of Philological Sciences, Associate Professor, Kazakh National Technical University named after Satpayev \\ a.gulnara70@mail.ru
}

\section{Saule Berkimbaeva}

Candidate of Pedagogical Sciences, Associate Professor, Kazakh National Technical University named after Satpayev saule-berkimbaeva@mail.ru

\section{Zanipa Bekmambetova}

Candidate of Pedagogical Sciences, Associate Professor, Kazakh National Technical University named after Satpayev bzanipa@mail.ru

\section{Tolkyn Kalbirova}

Master of Pedagogical Sciences, Senior Lecturer, Kazakh National Technical University named after Satpayev kalbirovatol@mail.ru

\section{Doi:10.5901/mjss.2015.v6n3s1p253}

\section{Abstract}

The article discusses the main challenges formation of culture communication of students, the communicative approach to methods of learning foreign language. Introduction of technologies formation of communicative culture was the optimization of the educational process and promoted the development of communicative culture of students in the context of the general culture of modern society. For the purpose the harmonious development of communicative culture of students, the teaching of humanities subjects in the experimental groups based on using intersubject approach, stimulating the communicative activities of students, achievement of variation in the representation of different forms of learning. Stimulation of professional orientation in communicative activities of students made possible through the organization of seminars, discussions and debates on foreign language communication. The dynamics of the indicators of formation of communicative culture was investigated throughout the experiment by observing and modeling indicators of formation of communicative culture of students. This allowed to analyze in detail the specifics of communicative behavior of each group and to reveal efficient ways of of pedagogical leadership of educational activity.

Keywords: communicative culture, teaching process, communicative approach, teaching technology, professional communication, active dialogue, foreign communication.

\section{Introduction}

The problem of formation of communicative culture of higher school students should be viewed as the unified complex of actions associated with the revision of approaches to education as well as taking into account the global, state and local tasks related to the cultivation of market relation ideology and sustainable development of society. The younger generation, primarily, the most educated and avant-garde part thereof - graduates of higher educational institutions are destined to renew the state economy.

There is a process of reorganization of social relations in Kazakhstan embarked on the course of independent development, therefore, the responsibility for the formation of student communicative culture has been assigned to the education system which is a social institution of society designed to transfer the most important part of accumulated human experience to younger generation.

As there is a simultaneous accumulation of knowledge and formation of the entire system of world perception by a person during the period of learning at higher education institutions, then a science-based and rational use of the 
technology of formation of student communicative culture promotes the development of value orientations of modern specialists, an ability to adaptation in the labor market and self-realization in the society after graduation. The development and testing of this technology was the essence of performed experimental work.

\section{Methodology}

Any certain aspects of the formation of communication culture and its components have been considered by such Kazakhstani scientists as A. Begimova [1], S. Kozybayeva [2], K. Koishiyev [3], G. Kosymova [4], Y. Pogozheva [5], I. Smanov [3].

The researches of A. Nurzhanova developing a communicative approach to foreign language teaching method [6] are of the greatest interest for our research.

\section{Research and Results}

The aim of the paper is a description and justification of the technology for formation of student communicative culture in the process of foreign language learning.

Statement of base material. The pedagogical experiment was carried out during 2013-2014 on the basis of the Kazakh National Technical University named after K. I. Satpayev

An ascertaining experiment consisted in the determination of the research problem quality:

- determination and description of the levels of formation of communicative culture of the experiment participants;

- selection of methods and preparation of student testing materials;

- testing of the levels of development of speech culture and communicational culture;

- familiarization with the specificity of humanitarian disciplines teaching;

- identification of causes of underdeveloped communicative culture of students demonstrated the average and low levels of formation of communicative culture in the process of testing.

Three sequentially linked level of formation of communicative culture - high, medium and low were determined as the indicators of formation. Let's consider each of them.

The high level is characterized by a value-motivational attitude to communication as a means of achieving goals in the process of communication with others, the understanding of the need to improve communication skills and speech culture, the ability to use these skills in all communicative situations, a wide variety of speech techniques and strategies of communicative behavior, regularity, consistency, advisability of their use in different communicative situations, the demonstration of creative activity in the communication process, high verbal intelligence, ability to make a positive impression, fast response in the dialogue.

The average level of formation of communicative culture is characterized by an insufficient prevailing valuemotivational attitude to communication culture as a means of self-realization and adaptation in social relations; underdeveloped skills of adaptation to different communicative situations; the demonstration of uncertainty and lack of activity in the dynamics of communication; developed skills of speech culture, but underdeveloped ability to use them in real communicative situations.

The low level is characterized by an incomprehension of the role of the communicative culture in individual selfdevelopment, inability to use accumulated communication skills to achieve goals set before the process of communication, weakly developed speech and inability to adapt to the dynamics of communicative situation, inability to make a positive impression on a partner in conversation, inability to lead in the dialogue and to achieve desired goals, the lack of inspiration and creative activity, low response speed to a speech of a communication partner.

The qualitative analysis of data that were obtained during the ascertaining experiment gave an opportunity to establish the reasons for insufficient development of the communicative culture of students who have the low and medium levels of its development. Such reasons include:

- uncertainty of the value and motivational orientation of students;

- lack of scientifically grounded approaches, technologies and methods in the educational process of higher schools which provide the formation of communication skills as indicators of professionalism of future specialists;

- lack of relationships between the material of humanitarian disciplines and disciplines of professional orientation;

- defiance of individual characteristics of student development in the process of academic communication; 
- insufficient development or absence of guidelines or workshops on professional and business communication issues;

- focusing on the development of speech and language skills in case of the ignoring of dynamics of communication culture formation indicators;

- inattention to the humanization of relations between teachers and students;

- occasional use of active group and individual forms of activity.

The data on the levels of speech/language competence of students were collected and causes of mistaken use of those or other language (speech) structures by students were identified due to the need to obtain full and objective information of linguistic knowledge and testing progress. The results were processed and combined in table 1.

Table 1 - Levels of student language/speech competence

\begin{tabular}{|c|c|c|}
\hline Assessment criteria & Experimental groups & Control groups \\
\hline \multicolumn{3}{|c|}{ Speech competence level } \\
\hline 1. Speech fluency & medium & high \\
\hline 2. Speech integrity & medium & high \\
\hline 3. Speech imagery & high & medium \\
\hline 4. Speech style & medium \\
\hline \multicolumn{3}{|c|}{ Language competence level } \\
\hline 1. Reading & high & high \\
\hline 2. Grammar & medium & low \\
\hline 3. Phraseology & medium & high \\
\hline 4. Word stock & low & medium \\
\hline
\end{tabular}

The analysis of results has confirmed that the process of perception of linguistic information by students has been influenced by the following factors:

- methodologies, technologies and methods of teaching;

- student individual characteristics;

- nature of group interaction during academic studies;

- interpersonal relations developing during a learning process.

The data collected has confirmed the need for a formative experiment assuming the introduction of technology for formation of communicative culture in the process of teaching of humanitarian disciplines and the organization of educational process in the experimental groups in accordance with the following algorithm:

1) scientific rationale of the essence of communicative culture formation as a professional values of future specialists;

2) consideration of pedagogical conditions that contribute to the effective formation of communicative culture of higher school students;

3) organization of group and individual, classroom and extra-curricular activities of students for the purpose of the development of communicative culture components;

4) organization of training of future specialists for professional communication at work places;

5) systematic control and monitoring of the dynamics of indicators of student communicative culture formation.

With this context and taking into account the features of teaching of humanitarian disciplines at higher education institutions we have organized an experiment concerning the introduction of the technology of communicative culture formation in educational processes. Let's describe the steps for implementation of the technology and monitor the dynamics of formation of communicative culture of students from the experimental groups.

1. The following steps were performed in order to create conditions for the development in future specialists of conscious attitude to the need of improvement of communicative culture skills:

- depth analysis of the components of student communicative culture, qualitative processing of ascertaining experiment data and identification of statistically important indicators of communicative culture development;

- explanation to students of communication role as a professional value of specialists in the modern society in the course of discussions, debates, lectures and seminars;

- formation of a positive and active position in communication due to the regular involvement of students in productive dialogues in the process of humanitarian discipline studies; 
- creation of the atmosphere of trust, cooperation, mutual assistance and creativity due to the rational organization of student group control, tutoring, support of student creative initiatives, supporting students in education and extracurricular activities;

- focusing of student attention on the features of business communication, assisting in the gaining of experience in business communication and correspondence;

- development of training manuals and humanitarian discipline course programs, the preparation of methodological recommendations for teachers based on the integration of humanitarian discipline material.

2. The stimulation of professional orientation in the communicative activities of students has been implemented due to the organization of seminars, discussions, debates on issues of foreign communication. The awareness by the participants of the experiment the need of formation of communicative culture was achieved due to:

- focusing of students attention on the importance thereof for future professional activity;

- organization of educational control of the process of student professional self-education with regard to communicative culture development features;

- evolvement of students in creative activity and active dialogues in the process of academic studies;

- definition and solution of tasks associated with professional practice of future professions;

- simulation of work tasks and situations of business communication in the process of educational communication.

3. During the formative experiment the learning activities of the students from experimental groups has been organized taking into account some pedagogical conditions which contribute to the formation of communication skills in the process of studying of humanitarian disciplines. This is the integration of different disciplines knowledge; the achievement of communicative orientation in teaching; the strengthening of interpersonal relations in student groups as well as between students and teachers; the stimulation of creative activity of students; introduction of cultural information in educational courses; the stimulation of communication in foreign languages; introduction into educational processes of teaching aids and methods that promote the growth of communicative activity and the implementation of those psychological qualities which are necessary for students for their future professional activity.

The teaching of humanitarian disciplines in the experimental groups based on the use of interdisciplinary approach, the stimulation of student communicative activities, the achievement of variability in the presentation of various forms of training for the purpose of harmonious development of student communicative culture.

4. The effective formation of communicative culture should be achieved due to the theoretical justification and approbation of teacher activity complex:

- organization of control and collection of objective information of the development of indicators of formation of speech and communication culture during the educational activity of students;

- activation of creative thinking through methodically developed assignments, topical conversations, discussions, contests and games;

- introduction of an elective course for formation of system thinking focused on the formation of logical thinking and speech, the ability to classify information, the sequence of thought and speech;

- conduct of psychological trainings and business games, the development of intensive methods for development of native and foreign communication, the strengthening of communicative orientation in foreign language teaching;

- development of professional self-consciousness of students-humanists for which a communication in native and foreign languages is the basis of professional activity. The following activities were performed for this purpose: the development of program for preparation to professional practices by specialty, practices on foreign languages as well as the organization of meetings of students with leading experts, rendering of assistance to students participated in the work of international and national conferences as well as participated in academic competitions, brain-rings, competitions in foreign languages and humanitarian disciplines;

- monthly testing by teachers of the levels of formation of student communicative culture;

- organization of extracurricular thematic communication case-studies, brain-rings, club of foreign languages, meetings and cultural exchange with native speakers, practical courses of communications networking in English;

- activation of creative thinking through methodically developed tasks, topical discussions, debates, contests; 
- introduction of an elective course on the development of system thinking which is focused on the formation of such indicators of communicative culture formation as consistency of thought and speech, ability to classification and distribution of information, consistency of thinking and speech;

- improvement of professional self-consciousness of students-humanists for which communication in the native and foreign languages is the basis of professional activity. This was achieved by the development of programs for training in professional practice by specialty and practice in foreign languages, arrangement of meetings with famous specialists by specialty, preparation of students to participation in international and domestic conferences, academic competitions, brain-rings, contests in foreign languages and humanitarian disciplines;

- clarification of the role of systematic testing with the aim of developing of student self-evaluation, selfeducation and self-consciousness.

5. The assurance of continuous diagnostics and monitoring of the dynamics of formation of student communicative culture has been carried out by:

- development of diagnostic tests which involved the identification of levels of formation of student communicative culture;

- implementation of the system of diagnostic tasks and tests involved the determination of the level of professional knowledge systematic nature:

- development and implementation into the educational activities of teaching exercises aimed at the activation of communication and at the same time at the diagnostics of the levels of development of communicative culture indicators;

- systematic modeling and control of the dynamics of development of student communicative culture components.

The dynamics of development of communicative culture formation indicators has been studied throughout the experiment by control and modeling of student communicative culture formation indicators. This has made it possible to analyze in detail the specifics of communicative behavior of each group and identify the rational ways of pedagogical control of training activities. Based on the analysis of obtained results it was prepared the classification of methodological teaching aids which contributed to the effective formation of qualities that characterize the dynamics of communication culture formation. The table 2 illustrates the results obtained. The qualities that serve as indicators of communication culture formation are listed in the left column of the table and pedagogical means of impact on the educational activities of students that facilitate the fast development of these qualities are listed in the right column.

Table 2 - Indicators of formation of communicative culture of young specialists and the ways of their formation in educational processes

\begin{tabular}{|l|l|}
\hline Indicators of Communication Culture Formation & Means Aimed at their Formation \\
\hline Ability to listen & Interviews, discussions, topical discussions \\
\hline $\begin{array}{l}\text { Planning experience } \\
\text { Strategic thinking }\end{array}$ & $\begin{array}{l}\text { Description of events and processes, component analysis of information, } \\
\text { compositions, preparation of annotations, writing of papers }\end{array}$ \\
\hline Ability to think clearly under stress & $\begin{array}{l}\text { Discussions, role plays, contests, brain rings, organization of academic } \\
\text { competitions, tests }\end{array}$ \\
\hline Personal keenness & $\begin{array}{l}\text { Substitution and replacement of data in exercises, heuristic tasks, crossword } \\
\text { puzzles, interviews, grammatical exercises }\end{array}$ \\
\hline Self-confidence & Selection of answer variants, tests, performance of tasks that are limited in time \\
\hline Ability to objective analysis and self-searching & $\begin{array}{l}\text { Plays involving the analysis, classification and distribution of information, retelling, } \\
\text { abstracting, descriptions, discussions, debates }\end{array}$ \\
\hline Ability to classification and distribution of knowledge & $\begin{array}{l}\text { Grammar exercises, translation, abstracting of articles, description of schemes } \\
\text { and processes }\end{array}$ \\
\hline Inner desire to achieve the goal & $\begin{array}{l}\text { Contests, settlements of communicative situations, performance of tasks limited in } \\
\text { time }\end{array}$ \\
\hline Inspiration & Writing of compositions, team games, contests \\
\hline Image thinking & Description of schemes and processes \\
\hline Reflexive thinking & Grammar exercises, substitution of data, modeling \\
\hline Insistence in achievement of an objective & Retelling, grammar exercises, team games \\
\hline Orientation on self-education and self-improvement & $\begin{array}{l}\text { Exercises that require individual work, various types of independent } \\
\text { extracurricular work }\end{array}$ \\
\hline Ability to convince & Discussions, role plays, contests, brain rings, tests \\
\hline
\end{tabular}


According to the research results the level of speech culture increased approximately by $15 \%$, and the level of communication culture formation has increased by $20 \%$ in the experimental groups.

\section{Conclusion}

All the performed experimental work and the experience of control of the nature of educational activity of studentshumanists have allowed us to make conclusions on the specifics of formation of student communicative culture.

1. During the experiment it has been observed that qualitative features of student language training are important in the formation of communicative culture as a professional value of future specialists.

2. The indicators of the dynamics of communicative culture formation are directly dependent on the number of hours of study, quality of teaching, technologies and techniques used by teachers of foreign languages.

3. It was found during the experiment that in addition to the mastery of foreign language and speech structures, each student used an individual orientation scheme which was developed in everyday communication in the native language. The students tried to compensate of missing knowledge of foreign languages using nonlinguistic means: ability to conduct a conversation in a certain direction, making compromises, evading a direct answer, achieving a desired objective using previously accumulated experience of communication and general culture. In educational dialogues in a foreign language the students of higher educational institution used the qualities of modern man which such a higher educational institution tends to form for each graduate within the framework of preparation of students to future professional activities.

4. The introduction of the technology of formation of communicative culture of future specialists into the process of teaching of humanitarian disciplines has been optimized the educational process and at the same time contributed to the formation of student communicative culture in the context of the general culture of the modern society.

\section{References}

Begimova A. Speech culture as the basis of the quality of professional preparation of future teachers // Izdenis (Search). - 2006. - No.4 (2). - pp. 232-234.

Kozybayeva S. Culture and individual style of communication // Ult tagylymy (Nation's patrimony). - 2007. - 1 (2). - pp. 277-278.

Smanov I., Koishiyev K. Characteristics of culture in the aspect of personality adaptation // Ult tagylymy (Nation's patrimony). - 2007. - 1 (2). - pp. 196-200.

Kosymova G. Development of the society information culture: perspectives and ways of solution // Ult tagylymy (Nation's patrimony). 2007. - No.4. - pp. 117-118.

Pogozheva Y. Psychological approaches to communicative activity study // Izdenis (Search). - 2006. - No.3. - pp. 314-320.

Nurzhanova A. Communicative approach in the methodology of foreign language teaching // Izdenis (Search). - 2006. - No.4 (2). - pp. 315-318.

Floud. J. «Making Adults More Equal: The Scope and Limitations of Public Educational Policy» in Peter Cox, N.B. Miles and John Peel (eds.). Equality and Inequality in Education, Nevv York, 1974. - P.37-51. 